

\section{The Mediating Role of Environmental Attitude on the Impact of Environmental Concern on Green Product Purchasing Intention}

\section{Ebru Onurlubaș}

\section{Introduction}

One of the most important issues causing environmental problems is that; wishes, needs and consuption habits of humankind do differ every day with globalization. In time, the environmental problems have climbed and natural resources have decreased, which led these issues to have more coverage in the media. As a result, activities on this subject have raised awareness among consumers and enabled them to be more careful about the products they use. In other words, the sensitivity of consumers towards the environmental problems have increased and consumers are observed to use environmetal friendly products, which are sensitive to the nature through all product phases. As the environmental focus and concentration have increased step by step on consumption, the firms giving importance to this issue are now taking care of consumers by satisfying their demands and needs. So, the number of firms choosing the green path for the products they manufacture has increased by time.

Since the consumers now have environmental concern, the concepts such as green product, green consumer, green marketing and environmental attitude have become significant subjects that should be focused (Kalafatis et al. 1999:441; Laroche et al. 2001: 515). Green or environmental friendly products are the ones which do not pollute the nature, don't consume natural resources, that are re-cyclable and protectable (Turhan et al. 2015). Green consumers do reflect environmental concerns more to their purchases and consuptions, compared to other consumers. Additionally, green consumers are also interested in the production, shortage of consumed resources and post-usage processes of products (Zinkhan ve Carlson, 1995:2). Green marketing is a marketing approach, which can be applied to consuption products, industrial products and services. Green marketing also includes various activities such as making changes in production process, modifying the product, changing the packaging strategy and improving advertsing plans (Alnıaçı, 2009). Attitude is described as a positive or negative reaction tendency of an individual, when faced with a stimulant (Oppenheim, 1992). If an individual has a postive attitude towards an object, he will behave and act positively to that object. Also, this individual will have a tendency to get closer, support and assist the mentioned object. On the other hand, an individual which has a negative attitude towards a particular object, will have a tendency to be uninterested about that object. Also, this individual will have a tendency to get away, criticize or even damage the mentioned object (Aydın, 2000). By the way, environmental aittude is described as positive or negative feelings towards specific elements of the environment as well as aims concerned with the environment (Hines et al. 1987: 4). The aim of this study is to investigate the impact of environmental concern on green product purchase intention, and to also investigate the mediating role of environmental attitude on the mentioned impact.

\section{Conceptual Framework of the Research and Hypotheses}

\section{Green Product}

Green product is generally described as the environmetal friendly product. Also, green product is expressed as the product, which assists the recycling and termination of waste, protecting and enlarging the environment by limited use of energy resources (Ottman et al. 2006). Parallel to another description, the green product protects the environment and aims to recycle the resources of nature as well as eliminating cease of resources (Shamdasani et al. 1993: 488). Moreover, the green product is stated as products, which don't have any negative effect on the environment, eliminate air pollution and similar negativenesses by preserving energy and resources even in the business life (Çabuk et al. 2008: 87). The basic criteria in the green product are satisfaction of consumers' demands and needs, sustainability of energy resources, harmlessness of product towards the environment and human health as well as the renewability of product (Uysal, 2006: 89-90).

If the green product concept should be explained with the $4 \mathrm{~S}$ formula in literature, we should state that these are environmental friendly products, which are able to (satisfy) the demands and needs of consumers, reflect (sustainability) for the continuity of resources, have (social acceptibility) in global context for not harming the environment and livings, and focus on (safety) in terms of consumer health (Erbaslar, 2007).

A product should have particular features, so that it can qualify as a green product. These features are indicated below: (Moisander, 2007:2);

- It should not affect human and animal health,

- It should not harm the environment before and after its usage,

- It should consume energy and other resources adequately,

- It should eliminate the usage of materials that can harm the environment,

- It should not cause unnecessary waste as a result of excessive packaging and short life cycle.

Consumers in fact experience difficulties in differenting green products from the others. As a solution to this complexity in the mind of consumers, eco labels and stickers are now used which is equivalent to some kind of confirmation. Eco labels and stickers have easy to understand signs, which emphasize that a product's environmental impact is lower than that of other products in similar categories (Morris, 1997: 11). 


\section{Green Consumer}

According to Elkington (1994), the green consumer avoids using products, which risk the health of consumers and others, have potential to significantly harm environment through production, usage and postusage, consume energy extensively, cause uncessary waste, endanger species and the environment, require unncessary usage, cause treating animals mercilessly and affect other countries negatively. Based on another definition, green consumer is the individual, who is interested in new products, runs research on information and shares his opinions with others concerning the products. Thus, green consumers are considered as opinion leaders and word-of-mouth advertisers (information providers). Also, green consumers are careful shoppers and they are not inclined to purchase without consideration. The green consumers give priority to the needs of environment and they run research about the products without any brand loyalty (Shrum et al. 1995:80).

Green consumers can affect the environment with their purchasing decisions. The consuming decisions of green consumers reflecting the social responsibility include specific components. These cover specific research, which can be listed as checking the manufacturers of purchased products, production operations and implementations, and the impact of raw materials on the environment through usage and post usage (Karaca, 2013). Green consumers present various consuming behaviors aimed at protecting the natural environment by using different methods such as purchasing green products, considering recycling and making savings on energy (Paço et al. 2013). Green consumers believe that, personal consumption is an effective method to protect the environment They also believe that, the environmental protection is a personal (individual) issue and it should not be solely left to the hands of government, environmentalists and scientists. Furthermore, green consumers are open minded and they are tolerant to new products as well as new ideas (Boztepe, 2012).

Based on the research of IISD (International Institute for Sustainable Development), general characteristics of green consumers are as follows (Boztepe, 2012): Exaggregating green behaviors, making environmental protection easy and being inclined to not trust the environmental arguements of corporations.

\section{Green Marketing}

Today, green marketing is a set of activities, which include all environmetal and natural friendship efforts in order to match the demands and needs of consumers. It is aimed to harm the environment in a minimum degree while these demands and needs are matched. Green marketing is also called and known as a reaction towards the goods and services used for design, production, packaging and labelling (Onurlubaş ve Dinçer, 2016: 26).
The green marketing approach can be investigated under four different phases (Erbaşlar, 2012: 96);

In the first phase, green products are designed for environmentalist consumers. Ecocredential products and automobiles working with alternative fuel technology can be shown as examples at this point. We can name this first phase as the green targeting.

In the second phase, green strategies are developed. As an example, environmentalist measures such as increasing the energy efficiency and producing less waste within the business can be mentioned here.

In the third phase, the manufacturing of nongreen products, in other words non-environmental friendly products are halted and only green products are manufactured.

However, it is not enough to be green or environmentalist in the fourth phase. The firm has reached to the social responsibility awareness by all means here. When the organizations reach green marketing awareness, this is generally based on the organizational culture and environmental elements.

\section{Environmental Concern}

The most important purpose of the humankind through history has been searching for ways to find resources (food, clothes, shelter, energy and other materialistic needs) from various ecosystems, in other words from the environment, which will let him to sustain his life. Also, the humankind has benefited from the resources of the nature for thousands of years without any concern. These resources have been used extensively to satisfy basic needs and in some cases, generating profits. Despite that, the nature has always renewed itself in a great extent and presented its resources over and over for the humankind's welfare. The fact that this cycle continued for a very long time without any problem has caused an incorrect perception as if the natural resources were limitless (Biner, 2014). However the population increase, higher usage of natural resources, limited environmental richness and the emergence of environmental problems in time have created a concern among people in terms of a healthy life and landing a good environment to next generations.

The environmental concern is an indicator that, individuals are showing an effort for raising awareness in terms of environmental sensitivity (Akehurst, 2012: 977). The term environmental concern is used to state the concern of individuals about environmenral changes today or in the future (Ay and Ecevit, 2005: 246). The term environmental concern is used to state the concern of individuals about environmenral changes today or in the future. It is pointed out that, environmental concern is reflected to the behaviors of various consumers. Also, it is understood that environmental concern has an impact on product selection, informative research and behaviors concerned with receycling and diversity (Minton ve Rose, 1997: 44). 
In the literature, there are many studies which have determined that environmental concern has a meaningful impact on green product purchasing intention. Some of these studies are Kim and Choi (2005); Khaola et. al. (2014); Mostafa (2009); Lizawati Aman, A.H. (2011); Kamonthip et al. (2017); Maichum et al. (2016) and Paul et al. (2016). Also, several studies have detected that, environmental concern has a meaningful impact on purchase intention towards green products. Examples of such studies are Kim and Choi (2005); Khaola et al. (2014); Mostafa (2009) ; Lizawati Aman, A.H. (2011); Kamonthip et al. (2017); Maichum et al. (2016) and Paul et al. (2016). Based on mentioned findings, the hypotheses below are developed and presented;

H1: Environmental concern has a meaningful (significant) impact on environmental attitude.

H2: Environmental concern has a meaningful (significanr) impact on purchase intention towards green products.

\section{Environmental Attitude}

Generally speaking, attitude is a preliminary tendency of reaction that a particular individual has towards any subject around his environment. Also, attitude is a regular act and behavior pattern of individuals towards specific objects as a result of former experiences. Individual patterns are formed as a result of an individual's upbringing and life-long experiences, which differentiates that particular person from others (Akdemir, 2008: 83). Attitude is an organized mental, emotional and behavioral preliminary tendency of reaction, which is developed based on experience, knowledge, emotion and motivation, and that is against the individual himself or against any object, social subject or incident around the individual (İncelioğlu, 2010: 13). In general terms, attitude is a positive or negative emotion that is developed towards an individual, object or situation. This is related with the belief that, it is formed by the knowledge of an individual about another individual, object or condition (Newhouse, 1990).

Environmental attitude is the sum of beliefs, emotions and environmental intentions of an individual about the environmental activities and issues (Schultz et al. 2004: 31), as well as the attitude and behavior patterns of an individual related with environmental feelings and thoughts. At this point, it will be wise to put forward that, if the individual will have a positive attitude towards the environmental, he will try to protect and recover it. However, if the individual will have a negative attitude towards the environment, he will be insensitive towards it, and in some cases may even have a tendency to harm it (Sabuncu, 2017).

Kim (2011) pointed out that, consumers with high environmental attitude have an intention to buy products that are considered environmental friendly. Alwitt \& Pitts (1996) presented that, environmental attitude indirectly affects the purchase intention of environmental friendly products. Kim \& Chung (2011: 43-44) did run a research on attitude of consumers towards organic personal care products. As a result of this research, it was found that, attitudes were a meaningful (significanr) variable affecting purchase intention. Cowan \& Kinley (2014) stated that, there existed a strong relationship between postive attitudes towards environmental friendly textile products and the purchase intention. Yadav and Pathak (2016) reported that, the environmental attitude had direct effects on their intention to purchase green products. Based on mentioned findings, the hypothesis below is developed and presented;

H3: Environmental attitude has a meaningful (significant) impact on purchase intention towards green products.

\section{Green Product Purchasing Intention}

Attitude is in a key position concerning the relationship between intention and behavior. If we should interpret the intention concept from the perspective of consumer and client, it will not be wrong to state that the intention occurs somewhere between evaluating purchasing alternatives and the realization of purchase. Purchase intention is described as the perceptional opinion (belief) level of a client towards buying a specific product or service (Bergeron, 2004: 117). Also, purchase intention represents the planning and purchasing willingness of consumers to buy a specific product in the future (Wu et.al.., 2011: 32). Concerning the purchase intention, evaluations and attitudes of consumers related to products or services ae important. When the consumers believe that a particular product or service is worth to buy, they do purchase that specific product or service (Madahi ve Sukati, 2012). Evaluations on purchase intention do reflect the purchasing behaviors in the future (Grewal et.al., 1998). Purchase intention of consumers is considered to a subjective tendency for a specific product and it can also be an important index to estimate and foresee consumer behaviors (Fishbein ve Ajzen, 1975).

Engel et. al. (1995) argue that, purchase intention can be categorized such as unplanned purchase, partially planned purchase and entirely planned purchase. Unplanned purchases are generally known as the purchases, which occur with a sudden emergence of stiumulation, not based on any plan. Partially planned purchases mean that, the consumer has made a decision only on a single product category or a specific object before buying a product, but he will make a decision on brands and types later in the store. Entirely planned purchases stand for a situation when the consumer has made a decision on a specific product and brand before visiting the store.

The fact that environmetal problems are taking a part in the media continuously and with an increasing pace have led to environental concern in individuals. Thus, consumers are observed to purchase green products while leaving non-green products on the shelf (Davis, 1993). In the recent years, the consciousness level of consumers is much higher and they are more inclined to purchase green products, which do not harm the environment or that harm the environment lower than other products. Green product purchasing intention of consumers determine their planning or purchasing will when buying a green product in the future. Green product purchasing intention is described as a consumer's plan to 
buy a particular green product through a specific period and the consumer's will to buy a particular good or service.

The literatüre does not include many studies, which investigate the mediating role of environmental attitude on the impact of environmental concern on green product purchasing intention. Thus, it is considered that this research may contribute to the literature and accordingly, the $\mathrm{H} 4$ hypothesis is presented below in this context.

H4: Envrionmental attitude has a mediating role (effect) on the impact of environmental concern on green product purchasing intention.

\section{METHODOLOGY}

\subsection{Aim of the Study}

The ever increasing population leads to the drain of natural resources and the drain of natural resources unconsciously causes natural devastation. Consumers who are aware of this fact and have environmental concern, have started to prefer recyclable products, which are environmentally sensitive that do not harm the nature in order to ensure the healthy life of themselves and future generations. The green product and green marketing have become more important as the environmental concern of consumers has increased in the recent years. Thus, some firms have developed marketing strategies accordingly and have concentrated on environmental activities for enabling their sustainability. Green product purchasing by cosumers who have environmental concern can let green products remain in the market and cause non-green products to decrease in numbers. This issue can help businesses to manufacture green products by focusing on environmental activities. Because of this fact, it is significant to investigate the environmental concern of consumers as well as factors directing consumers to improve their environmental attitude and green product purchasing intention. Thus, this study aims to investigate the mediating role of environmental attitude on the impact of environmental concern on green product purchasing intention. Moreover, this study aims to investigate the effect of environmental concern on environmental attitude and green product purchasing intention, as well as the impact of environmental attitude on green product purchasing intention.

\subsection{Scope, Limitations and Sample of the Research}

Research was limited with individuals who are living in the city of İzmir and are informed of green products. One of the non-random sampling methods, convenience sampling method was used for the face-toface questionnaires distributed to 410 individuals who were subject to this study. The most important limitation of the research is that, the study was only run in Izmir city center because of time and monetary scarcities. Based on the data of TÜIK (Turkish Statistical Institute), population of İzmir city was 4.279 .677 in 2017 (Tüik, 2018). After the universe was determined, the following formula was used to detect the sample volme (Arıkan,
2007): $z=$ statistical value $(1.96,95 \%$ confidence interval)

$$
n=\frac{N \cdot t^{2} \cdot p \cdot q}{d^{2} \cdot(N-1)+t^{2} \cdot p \cdot q}
$$

$\mathrm{N}=$ Universe (4 279 677)

$\mathrm{p}=0,5, \mathrm{q}=0,5$

$D=(e / z)^{2} \quad(0,0484 / 1,96)^{2}$
$D=$ Error rate $\quad(0,000554)$
$z=$ statistical value $(1.96, \% 95$ confidence interval $)$
$n=410$

Using the formula above, the sufficient sample size was determined as 410 with $0,0484 \%$ error rate and 95\% confidence interval. One of the non-random sampling methods, convenience sampling method was used for the face-to-face questionnaires. By the help of convenience sampling method, data can be collected from the universe with the easist, fastest and most economic way possible (Aaker et. al., 2007).

\subsection{Research Model and Hypotheses}

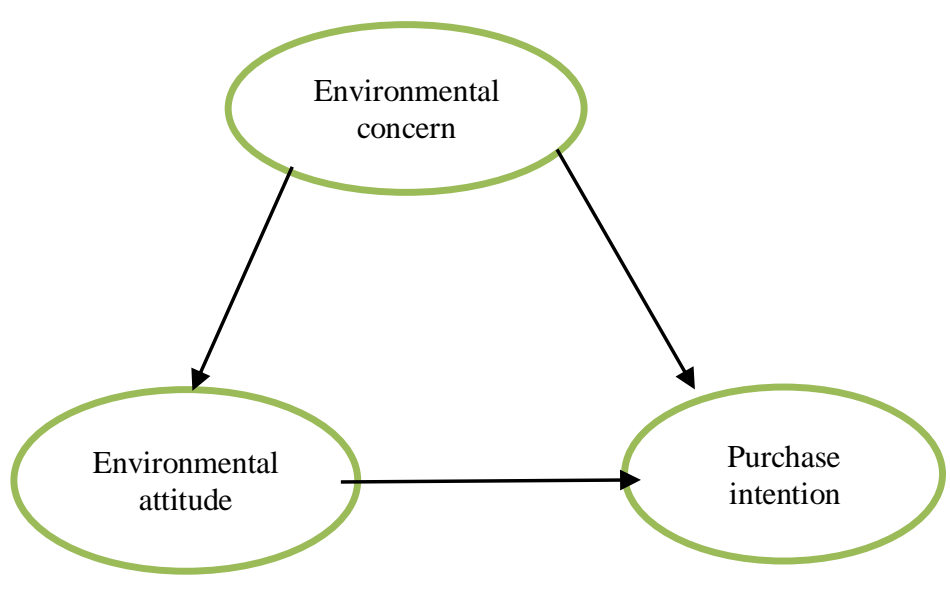

Figure 1: Research Model

This research includes the three variables of environmental concern, environmental attitude and green product purchasing intention. The research model is presented in figure 1 considering the fact that environmental concern has an impact on green product purchasing intention, and environmental attitude has a mediating role on the mentioned impact.

H1: Environmental concern has a meaningful (significant) impact on environmetal attitude

H2: Environmental concern has a meaningful (significant) impact on green product purchasing intention

H3: Environmental attitude has a meaningful (significant) impact on green product purchasing intention 
H4: Environmental attitude has a mediating role (effect) on the impact of environmental concern on green product purchasing intention

\subsection{Data Collection}

Research data were collected with face-to-face questionnaires. Questionnaires were distributed to consumers who are living in İzmir city and are informed of the green product. The questionnaire form was composed of two sections. The first section included 6 demographical items (questions). The second section included 6 items (questions) on environmental concern, 5 items (questions) on environmental attitude and 5 items (questions) on green product purchasing intention. Concerning the items (questions) on second section of research, studies of Maichum et al. (2016); Yadav and Pathak (2016); Mostafa (2009); Straughan and Roberts (1999); Kamonthip et al. (2017) were taken as a reference for preparing the environmental concern scale, studies of Kim and Han (2010); Maichum et al. (2016); Mark and Law, (2015) were taken as a reference for preparing the environmental attitude scale, studies of Guanghui et al., (2018), Berens et al. (2005); Dodds ve et al. (1991); Petroshius et al. (1987) Kanchanapibul et al. (2014); Kim et al. (2013); Mark and Law, (2015) were taken as a reference for preparing the green product purchasing intention scale. The research also benefited from the 5 Likert scale for questionnaire. The coding for 5 Likert scale was as follows; (1) Definitely disagree, (2) Disagree, (3) Indecisive, (4) Agree, (5) Definitely agree. The researcher received feedback from two experts on the internal validity of scales and the scale items were translated to Turkish. Then, a pilot study was run on 40 respondents in order to eliminate future potential errors and determining the clarity of questions. It was detected that all items were completely understood and perceived by respondents, so the final version of questionnaire was prepared. Reliability of scales was tested by the Cronbach Alpha coefficient. According to Özdamar (1999), a Cronbach Alpha value of $0,80-0,90$ is equivalent to high reliability and a Cronbach Alpha value of $0,90-1,00$ is equivalent to very high reliability. As a result of the relaibility analysis, Cronbach Alpha value of environmental concern scale was determined as 0,820 , so the reliability of environmental concern was high. Cronbach Alpha value of environmental attitude scale was 0,817 , so the reliability of environmental attitude was high. Cronbach Alpha value of green product purchasing intention scale was 0,726 , so the reliability of green product purchasing intention was normal. According to Sipahi et. al. (2008:89), Cronbach Alpha coefficient is accepted to be reliable when the value is 0,70 and above. In this context, all the scales of research are reliable.

\subsection{Data Analysis}

Data analysis of the research were run by SPSS 22 and AMOS 20 software. The relaibility of scales was calculated via Cronbach Alpha. Also, normality test was run after the reliability test, to see if data had a normal distribution. In regards to normality test, kurtosis and skewness values of data groups were analzyed. It is accepted that data groups with kurtosis and skewness values between +2 and -2 have normal distribution (George \& Mallery, 2003). Environmental concern had a skewness of $-0,063$ and kurtosis of $-0,359$. Environmental attitude had a skewness of 0,205 and kurtosis of $-0,373$. Green product purchasing intention had a skewness of $-0,36$ and kurtosis of $-0,264$.

In this context, it can be accepted that all dimensions of the research have normal distribution. Exploratory factor analysis was run to test the construct validity of all scales used in the study. Also, confirmatory factor analysis was run to validiate the dimensions after running exploratory factor analysis. Researcher can define models defending an important feature, arrange factors and test the sutiability of data for models with confirmatory factor analysis (Hoyle, 1995). The research investigated the relationship among variables to analyze the mediating role (effect) of environmental attitude, and to study the impact of environmental concern on green product purchasing intention. Then, the interaction between variables was tested with structural equation modelling in order to analyze the interaction among variables. In this context, environmental concern was determined as indepedent variable, green product purchasing intention was determined as dependent variable and environmental attitude was determined as mediating variable. Environmental concern, environmental attitude and green product purchasing intention which are included in the theoretical model to be tested are known as theoretical structures, latent variables or factors, since their structures can not be tested directly and because they are considered to be existent theoretically in social sciences (Byrne, 2010:4). Although structural equation modelling is known as asimultaneous equation modelling with latent variables, its foundations are based on both factor analysis and path analysis. Also, structural equation modelling helps to retrieve findings which can not be presented with other popular techniques, since it can be used for direct, indirect and total impact estimations via mediating and moderator variables (Kelly, 2011: 12). Structural equation modelling was used in this study in order to determine the mediating role (effect) of environental attitude on the impact of environmental concern on green product purchasing intention. First, relationship among variables were investigated and second, interaction among variables were analyzed using structural equation modelling. Structural equation modelling was also used to test other hypotheses. Structural equation modelling is a detailed statistical approach used to test the causal interrelation among latent variables - factors. Structural equation modelling can also be described as a series of statistical methods, which present hypothesis test approach to the multivariable analysis of structural theory (Timm, 2002; Tomer, 2003).

\section{Research and Findings}

Cronbach Alpha was calculated and exploratory factor analysis was run for relability and avilability determination of measurement scales.

Based on the realibility analysis results, Cronbach Alpha for "Environmental Concern Scale" is $\alpha=0,812$, while it is $\alpha=0,877$ and $\alpha=0,716$ for "Environmental Attitude Scale" and "Purchasing Intention Scale" respectively. It is determined that, all scales are reliable. Then, normality test was run. 
According to the results of normality test, environmental concern had a skewness of $-0,063$ and kurtosis of $-0,359$. Environmental attitude had a skewness of 0,205 and kurtosis of $-0,373$. Green product purchasing intention had a skewness of $-0,36$ and kurtosis of $-0,264$. It is accepted that data groups with kurtosis and skewness values between +2 and -2 have normal distribution (George \& Mallery, 2003). In this context, it can be accepted that all dimensions of the research have normal distribution. Also, Kaiser Meyer Olkin and Bartlett test results were considered to decide whether factor analysis results are interpretable. For the construct validity study, following results were retrieved: Kaiser Meyer Olkin $=0,820$ and Bartlett $(\mathrm{p}<0,01)$ for environmental concern scale, Kaiser Meyer Olkin $=0,817$ and Bartlett $(\mathrm{p}<0,01)$ for environmental attitude scale, Kaiser Meyer Olkin=0,726 and Bartlett $(\mathrm{p}<0,01)$ for green product purchasing intention. It was revealed that, exploratory factor analysis could be run with these test analysis results. Test method by rotation was not used for the research's factor analysis. The reason is that, when all scales are assessed and tested via factor analysis separately, they can be listed under one single dimension (scale).

When the demographics of questionnaire respondents are analyzed, it is observed that $49,0 \%$ are males, and 51,0\% are females. Also, when the ages of respondents are investigated, it is seen that, $13,2 \%$ of respondents are between $18-23,12,7 \%$ are between 24 $29,16,6 \%$ are between $30-35,13,9 \%$ are between $36-41$, $14,8 \%$ are between $42-47,14,4 \%$ are between $48-53$, $9,0 \%$ are between $54-59$, and 5,4\% are 60 and above. In terms of marital status of respondents, $43,2 \%$ are married, $52,4 \%$ are single and $4,4 \%$ are divorced (Table $1)$.

Concerning the education levels of respondents, $8,5 \%$ have elementry school, $10,5 \%$ have middle school, 29,3\% have vocational school, 39,5\% have undergraduate, $7,8 \%$ have master's and $4,4 \%$ have doctorate (Ph.D.) diplomas (Table 1).

In regards to monthly average income levels of families that are subject to the research, it is determined that $4,1 \%$ have a monthly average income of $1000 \mathrm{TL}$ and below, 7,6\% have a monthly average income between 1001-1500TL, 6,3\% have a monthly average income between $1501-2000 \mathrm{TL}, 19,8 \%$ have a monthly average income between 2001-2500TL, 15,1\% have a monthly average income between 2501-3000TL, 12,0\% have a monthly average income between 3001-3500TL, $20,7 \%$ have a monthly average income between 3501 $4000 \mathrm{TL}$, and $14,4 \%$ have a monthly average income of 4001TL and above. When occupations of respondents are taken into consideration, it is observed that, 3,7\% are retired, 25,5\% are government officials, 32,0\% are private sector employees, $13,4 \%$ are housewives, $10,0 \%$ are regular employees (blue-collar workers), 9,5\% are self employed and 5,9\% are students (Table 1).

\section{Table 1. Demographics of Consumers}

\begin{tabular}{|l|l|l|l|l|l|}
\hline Gender & Frequency & Percent & Age & Frequency & Percent \\
\hline Female & 209 & 51,0 & $18-23$ & 54 & 13,2 \\
\hline Male & 201 & 49,0 & $24-29$ & 52 & 12,7 \\
\hline Total & 410 & 100,0 & $30-35$ & 68 & 16,6 \\
\hline $\begin{array}{l}\text { Educational } \\
\text { status }\end{array}$ & Frequency & Percent & $36-41$ & 57 & 13,9 \\
\hline $\begin{array}{l}\text { Primary school } \\
\text { degree }\end{array}$ & 35 & 8,5 & $42-47$ & 61 & 14,8 \\
\hline $\begin{array}{l}\text { Secondary school } \\
\text { degree }\end{array}$ & 43 & 10,5 & $48-53$ & 59 & 14,4 \\
\hline Associate's degree & 120 & 29,3 & $54-59$ & 37 & 9,0 \\
\hline Bachelor's degree & 162 & 39,5 & 60 and over & 22 & 5,4 \\
\hline Master's degree & 32 & 7,8 & Total & 410 & 100,0 \\
\hline Doctorate's degree & 18 & 4,4 & Marital status & Frequency & Percent \\
\hline Total & 410 & 100,0 & Maried & 177 & 43,2 \\
\hline Profession & Frequency & Percent & Single & 215 & 52,4 \\
\hline Retired & 15 & 3,7 & Divorced & 18 & 4,4 \\
\hline Civil servant & 105 & 25,5 & Total & 410 & 100,0 \\
\hline $\begin{array}{l}\text { Private } \\
\text { Employee }\end{array}$ & 131 & 32,0 & $\begin{array}{l}\text { Monthly incomes } \\
\text { (TL) }\end{array}$ & Frequency & Percent \\
\hline Housewife & 55 & 13,4 & 1000 and below & 17 & 4,1 \\
\hline Worker & 41 & 1,0 & $1001-1500$ & 31 & 7,6 \\
\hline Self-Employment & 39 & 9,5 & $1501-2000$ & 26 & 6,3 \\
\hline Student & 24 & 5,9 & $2001-2500$ & 81 & 19,8 \\
\hline Total & 410 & 100,0 & $2501-3000$ & 62 & 15,1 \\
\hline & & & $3001-3500$ & 49 & 12,0 \\
\hline & & & $3501-4000$ & 85 & 20,7 \\
\hline & & & Total ve üzeri & 59 & 14,4 \\
\hline & & & 410 & 100,0 \\
\hline
\end{tabular}

Table 2. Exploratory Factor Analysis Results

\begin{tabular}{|c|c|c|c|}
\hline Factor & Itenss (Questions) & \begin{tabular}{l|l|} 
Total \\
variance \\
explanatio \\
n r rate $(9 \%)$
\end{tabular} & $\begin{array}{l}\text { Factor } \\
\text { Loads }\end{array}$ \\
\hline \multirow{6}{*}{$\begin{array}{l}\text { Environmenta } \\
\text { Concern }\end{array}$} & $\begin{array}{l}\text { Q8.1. Environmental (natural) pollution is one of nuty } \\
\text { future concems }\end{array}$ & \multirow{6}{*}{54,447} & , 8222 \\
\hline & $\begin{array}{l}\text { 8.2. Balance of the nature can be damaged easily, } \\
\text { because it is very gensitive }\end{array}$ & &, 852 \\
\hline & $\begin{array}{l}\text { Q8.3. Humankind should live in harmony with the } \\
\text { nature, so that they can continue their lives }\end{array}$ & &, 526 \\
\hline & $\begin{array}{l}\text { Q8.4. When humans interfere with nature, it will } \\
\text { cause serious consequences }\end{array}$ & &, 781 \\
\hline & $\begin{array}{l}\text { Q8.5. I am concemed about the polluted sir's effects } \\
\text { on me and my family }\end{array}$ & &, 645 \\
\hline & $\begin{array}{l}\text { Q8.6. I mm concemed about the world's current } \\
\text { natural (environmental) situstion }\end{array}$ & & ,751 \\
\hline \multicolumn{4}{|c|}{$\begin{array}{l}\text { Skewness: }-0,063 \quad \text { Kurtosis: }-0,359 \\
\text { KMOO }=0,820 ; \text { Bartlett's Test of Sphericity ChiS quare }=921,815 ; \mathrm{df}=15 ; \\
\mathrm{p}=, 000 ; \text {; Total Variance Exphined }: 0654,447 ; \text { Cronbach's Alpha: } 812\end{array}$} \\
\hline \multirow{5}{*}{$\begin{array}{l}\text { Environmenta } \\
\text { Attitude }\end{array}$} & $\begin{array}{l}\text { Q9.1. It is a good idea to use grean product for } \\
\text { protecting the nature }\end{array}$ & \multirow{5}{*}{67,285} &, 842 \\
\hline & $\begin{array}{l}\text { Q9.2. I would pay tax without hesitation in order to } \\
\text { decrease air pollution }\end{array}$ & &, 832 \\
\hline & $\begin{array}{l}\text { Q9.3. I have a favorable attitude tow ards green } \\
\text { products }\end{array}$ & &, 831 \\
\hline & $\begin{array}{l}\text { Q9.4. I am ready to dacrease my consumption for } \\
\text { protecting the nature }\end{array}$ & & .788 \\
\hline & $\begin{array}{l}\text { Q.5. If there will be reactive organizations and } \\
\text { gvents to protect the nature, I would participate }\end{array}$ & &, 806 \\
\hline \multicolumn{4}{|c|}{ 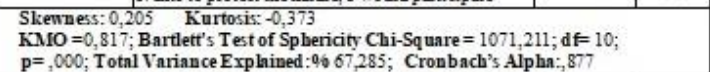 } \\
\hline \multirow{5}{*}{$\begin{array}{l}\text { Green } \\
\text { Product } \\
\text { Purchasing } \\
\text { Intention }\end{array}$} & $\begin{array}{l}\text { Q10.1. I purchase green products which do not harm } \\
\text { the nature, although they are more expensive than } \\
\text { other products }\end{array}$ & \multirow{5}{*}{50,443} &, 822 \\
\hline & $\begin{array}{l}\text { Q10.2. Intend to purchase green prodicts next tims } \\
\text { becsuse of their positive environmental contribution }\end{array}$ & & ,686 \\
\hline & $\begin{array}{l}\text { Q10.3. If I want to buy a product this type, I would } \\
\text { purchase an enviroumental friendly grems product }\end{array}$ & &, 477 \\
\hline & $\begin{array}{l}\text { Q10.4. I always intent to buy this gresn product any } \\
\text { time which does not ham the nature }\end{array}$ & &, 711 \\
\hline & $\begin{array}{l}\text { Q10.5. I prefer to purchase products with smaller } \\
\text { packages which do not ham the nature }\end{array}$ & &, 770 \\
\hline
\end{tabular}

When Table 2 is considered, it is observed that environmental concern dimension is composed of 6 items (questions) and factor loads vary between 0,526 and 0,852 . Environmental concern dimension explains $54,447 \%$ of the variance. Environmental attitude dimension is composed of 5 items (questions) and factor loads vary between 0,788 and 0,842 . Environmental attitude dimension explains $67,285 \%$ of the variance. Green product purchasing intention dimension is composed of 5 items (questions) and factor loads vary between 0,477 and 0,822 . Green product purchasing intention dimension explains $50,443 \%$ of the variance. In practice, generally a value of 0,45 and above is 
considered to be a good rate for factor load coefficients, which explain the relationship between items (questions) and the related factors (Büyüköztürk, 2002: 118). In this context, since factor loads of all dimensios were above 0,45 , none of them were removed from the scale. Confirmatory factor analysis is presented in Table 3. Confirmatory factor analysis is a more advanced and detailed technique, which is used to test the latent variables and related theories (Tabachnick and Fidell, 2014). So, confirmatory factor analysis is more like a model testing theories, rather than being a model presenting theories (Henson and Roberts, 2006; Stevens, 2002).

Table 3. Means, Standard Deviations and Correlation Values for the Variables

\begin{tabular}{|l|c|c|c|c|c|}
\hline Variables & Mean & Std. Deviation & l & $\mathbf{2}$ & $\mathbf{3}$ \\
\hline $\begin{array}{c}\text { Environmental } \\
\text { Attitude }\end{array}$ & 2,8127 & 0,89006 & 1 & & \\
\hline $\begin{array}{l}\text { Green Product } \\
\text { Purchasing } \\
\text { Intention }\end{array}$ & 3,5220 & 0,75026 &, $210^{* *}$ & 1 &, \\
\hline $\begin{array}{l}\text { Environmental } \\
\text { Concern }\end{array}$ & 3,3207 & 0,78307 &, $391^{*}$ &, $168^{* *}$ & 1 \\
\hline
\end{tabular}

When the correlation results are considered among variables, it is seen that all the three variables have a meaningful relationship (correlation) with each other. A postive and weak correlation is detected between environmental attitude and green product purchasing intention $(\mathrm{r}=0,210 \mathrm{p}<0,01)$, a positive and moderate correlation is detected between environmental attitude and environmetal concern $(\mathrm{r}=0,391 \mathrm{p}<0,01)$, a positive and weak correlation is detected between purchasing intention and environmental concern $(r=0,168$ $\mathrm{p}<0,01$ ) (Table 3). In line with the relationships (correlations) gathered as a result of analysis, structural equation modelling to determine the mediating role (effect) of environmental attitude on the impact of environmental concern on green product purchasing intention is presented in Figure 2.

Table 4. Confirmatory Factor Analysis

\begin{tabular}{|c|c|c|c|c|c|c|c|c|}
\hline \multirow[b]{2}{*}{$\begin{array}{l}\text { Adaptive } \\
\text { Scales }\end{array}$} & \multirow[b]{2}{*}{$\begin{array}{l}\text { Good } \\
\text { Fit }\end{array}$} & \multirow[b]{2}{*}{$\begin{array}{l}\text { Acceptable } \\
\text { Adaptive } \\
\text { Values }\end{array}$} & \multicolumn{3}{|c|}{ Adaptive Values of Scales } & \multicolumn{3}{|c|}{$\begin{array}{l}\text { Moderated Scale Confirmatory } \\
\text { Factor Analysis Adaptive Values }\end{array}$} \\
\hline & & & $\begin{array}{l}\text { Environm } \\
\text { ental } \\
\text { Concern }\end{array}$ & $\begin{array}{l}\text { Environ } \\
\text { mental } \\
\text { Attitude }\end{array}$ & $\begin{array}{c}\text { Green } \\
\text { Product } \\
\text { Purchasi } \\
\text { ng } \\
\text { Intention }\end{array}$ & $\begin{array}{l}\text { Environm } \\
\text { ental } \\
\text { Concern }\end{array}$ & $\begin{array}{c}\text { Environm } \\
\text { ental } \\
\text { Attitude }\end{array}$ & $\begin{array}{c}\text { Green } \\
\text { Product } \\
\text { Purchasi } \\
\text { ng } \\
\text { Intention }\end{array}$ \\
\hline $\begin{array}{l}T^{2} / \mathrm{d}(\mathrm{CMI} \\
\mathrm{IDF} / \mathrm{df})\end{array}$ & $\leq 3$ & 5.5 & 6,860 & 20,306 & 9,439 & 1,358 & 2,882 & 2,997 \\
\hline GFI & $\geq 0,90$ & $0,89-0,85$ & 9,952 & 909 & 9,957 & 997 & 995 & 991 \\
\hline CFI & 20,97 & $\begin{array}{l}\geq 0,95 \\
\geq 0,90\end{array}$ & 942 & 910 & 909 & 999 & 996 & 987 \\
\hline RISSEA & $\$ 0,05$ & $0,06-0,08$ & 120 & 217 & 144 & 030 &, 068 & 0,070 \\
\hline NFI & 20,95 & $0,94 \cdot 0,90$ & 933 & 906 & 900 & 997 & 995 & 981 \\
\hline RIIR & $\$ 0,05$ & $0,06-0,08$ & 0,01 &, 060 & 0,055 & 015 & 017 & 022 \\
\hline
\end{tabular}

Resource: Meydan, C. H., Şeşen, H. (2011). Yapısal Eşitlik Modellemesi AMOS Uygulamaları (1 ed.). Ankara: Detay Yayınevi (Adaptive Scales).
Confirmatory factor analysis was run separately for each scale. The retrieved adaptive values for environmental concern scale are calculated as follows as a result of the confirmatory factor analysis; CMINDF: 6,860, GFI: 0,952, CFI: 0,942, RMSEA: 0,120, NFI: 0,933, RMR: 0,61. The values are CMINDF:20,306, GFI: 0,909, CFI: 0,910, RMSEA: 0,217, NFI: 0,906, RMR: 0,60 for the environmental attitude scale and they are CMINDF: 9,439, GFI: 0,957, CFI: 0,909, RMSEA: 0,144 , NFI: 0,900, RMR: 0,55 for the purchasing intention scale. These values do not stand for good or acceptable adaptive volumes. Thus, items (questions) with low beta values were removed from the model and covariance relationship was established to ensure adaptive values of the model. Covariance relationship was established between e1-e5 error terms for the environmental concern scale and Q8.3 item (question) was removed. After the final version of the model, confirmatory factor analysis was run and the good adaptive values of scale was analyzed. The moderated adaptive values of environmental concern scale was calculated as CMINDF: 1,358, GFI: 0,997, CFI: 0,999, RMSEA: 0,030, NFI: 0,997 and RMR: 0,015. As observed in Table 3, all adaptive values indicate a "good adaptation". Model is acceptable at its current condition. Covariance relationship was estabished between "e1-e5", "e5-e3" and "e5-e4" error terms and no items (questions) were removed for the environmental attitude scale. Moderated adaptive values of the environmental attitude scale was calculated as CMINDF: 2,882, GFI: 0,995, CFI: 0,996, RMSEA: 0,068, NFI: 0,995 and RMR: 0,017. As seen in Table 3, RMSEA indicates an acceptable adaptation, while all other adaptive values indicate a "good adaptation". Model is acceptable at its current condition. Covariance relationship was estabished between "e3-e5" and "e5-e4" error terms and no items (questions) were removed for green product purchasing intention scale. Moderated adaptive values of the green product purchasing intention was calculated as CMINDF: 2,997, GFI: 0,991, CFI: 0,987, RMSEA: 0,070, NFI: 0,981 and RMR: 0,022. Based on Table 3, RMSEA indicates an acceptable adaptation, while all other adaptive values indicate a "good adaptation". When Table 3 above is taken into consideration, results of the moderated confirmatory factor analysis adaptive scale values (CMINDF, RMSEA, GFI, CFI, RMR, NFI) show that, model is in line with data and there exists a valid and reliable scale.

\section{Structural Equation Modelling Results}

The relationship among observed variables and their implicit variables are desribed as the measurement model, and the relationship among implicit variables is defined as the structural model in structural equation modelling (DiLalla, 200: 440). A two phase model where the measurement model is tested first and the structural model is tested later is accepted more in structural equation modelling compared to a single phase approach where measurement model and structural model are analyzed simultaneously (Kline, 2005: 216).

Path analysis adaptive values belonging to the research model formed to determine the mediating role of environmental attitude on the impact of environmental concern on green product purchasing intention is indicated in Table 5. 
Table 5. Model Adaptive Values

\begin{tabular}{|l|c|c|c|}
\hline Adaptive Scales & Good Fit & $\begin{array}{c}\text { Acceptable Adaptive } \\
\text { Values }\end{array}$ & New Structural Model \\
\hline$\chi^{2} /$ df (CMII/df) & $\leq 3, \leq 5$ & $\leq 4-5$ & 3,018 \\
\hline GFI & $\geq 0,90$ & $0,89-0,85$ &, 925 \\
\hline CFI & $\geq 0,97$ & $\geq 0,95, \geq 0,90$ &, 935 \\
\hline RVSEA & $\leq 0,05$ & $0,06-0,08$ & 070 \\
\hline NFI & $\geq 0,95$ & $0,94-0,90$ &, 906 \\
\hline RVR & $\leq 0,05$ & $0,06-0,08$ &, 070 \\
\hline
\end{tabular}

Table 5 indicates values such as $\chi 2$ : Ki square (CMIN) df (Degrees of Freedom): 3,018; RMSEA (Root Mean Square Error of Approximation); 0,70; CFI (Comparative Fit Index):935; GFI (Goodness of Fit Index): 0,925; RMR (Root Mean Square Residual): 0,70. Based on these values, all adaptive scales are within acceptable limits considering the goodness of fit indexes.

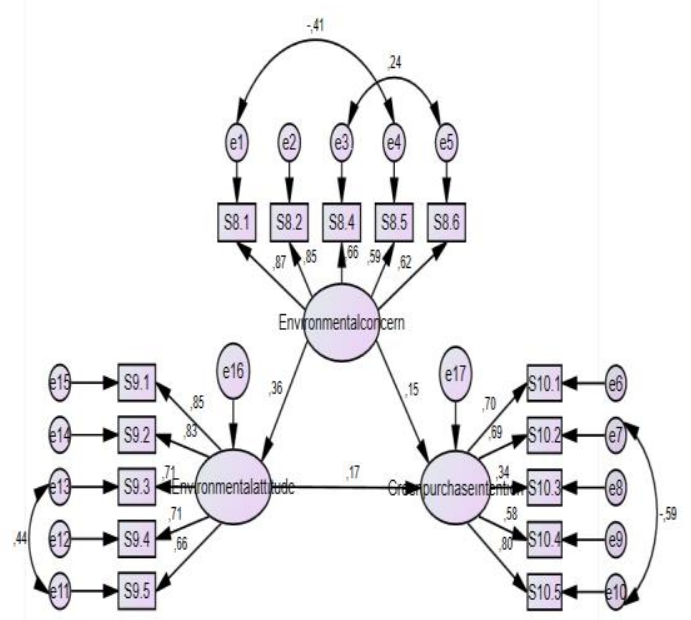

Figure 2. : The Mediating Role of Environmental Attitude on the Effect of Environmental Concern on Green Product Purchasing Intention

Figure 2, results of the moderated confirmatory factor analysis adaptive scale values (CMINDF, RMSEA, GFI, CFI, RMR, NFI) show that, model is in line with data and there exists a valid and reliable scale.

Table 6. The formed structural model related to the aim and hypotheses of research.

\begin{tabular}{|l|l|l|l|l|l|l|l|}
\hline Hypothesis & Path correlation & Estimates & $\begin{array}{l}\text { Standard } \\
\text { ized } \\
\text { estimates }\end{array}$ & $\begin{array}{l}\text { Standard } \\
\text { error }\end{array}$ & $\begin{array}{l}\text { t- } \\
\text { Value }\end{array}$ & P & Results \\
\hline Hl & $\begin{array}{l}\text { Environmental concem } \rightarrow \\
\text { Environmentalattitude }\end{array}$ & 0,337 & 0,365 &, 060 & 6,389 & 0,000 & Supported \\
\hline H2 & $\begin{array}{l}\text { Environmental concem } \rightarrow \\
\text { Green Purchase intention }\end{array}$ & 0,147 & 0,148 &, 059 & 2,490 & 0,013 & Supported \\
\hline H3 & $\begin{array}{l}\text { Environmentalattitude } \rightarrow \\
\text { Green Purchase intention }\end{array}$ & 0,182 & 0,170 &, 066 & 2,769 & 0,006 & Supported \\
\hline
\end{tabular}

Table 6 presents the formed structural model related to the aim and hypotheses of research. Based on the findings in table 2, standardized regression coefficient is $\beta=0,365, \mathrm{t}=6,389, \mathrm{p}=0,000$ and $\mathrm{p}$ significance level is $\mathrm{p}<0,001$ between environmental concern and environmental attitude dimensions. Based on this finding, $\mathrm{H} 1$ hypothesis is accepted. Also, environmental concern has a moderate level of significance on environmental attitude towards the green product.

Standardized regression coefficient is $\beta=0,148$, $\mathrm{t}=2,490, \mathrm{p}=0,013$ and $\mathrm{p}$ significance level is $\mathrm{p}<0,001$ between environmental concern and green product purhcasing intention dimensions. Based on this finding, $\mathrm{H} 2$ hypothesis is accepted. Also, environmental concern has a weak and significant impact on green product purchasing intention.

Standardized regression coefficient is $\beta=0,170$, $\mathrm{t}=2,769, \mathrm{p}=0,06$ and $\mathrm{p}$ significance level is $\mathrm{p}<0,05$ between environmental attitude and green product purchasing intention dimensions. Based on this finding, H3 hypothesis is accepted. Environmental attitude has a weak and significant impact on green product purchasing intention.

In order to analyze the mediating impact, independent variable should have an effect on mediating variable and dependent variable. Also, mediating variable should have an effect on the dependent variable. A partial mediating effect exists if there is a meaningful (significant) decrease on the impact of independent variable on the dependent variable when mediating variable is included to the model with the independent variable. A complete (full) mediating effect exists if the impact of independent variable on the dependent variable is eliminated when mediating variable is included to the model with the independent variable (Baron and Kenny, 1986: 1175). When a detailed analysis is run on the model with this purpose and motivation, both direct and indirect effects can be determined. The indirect impact of a variable on the other variable is possible wih a mediating variable, and thus a more detailed information is gathered about the impact of an independent variable on the dependent variable (Çetin Gürkan and Demiralay, 2017: 80). This study presents direct, indirect and total impacts about variables that are put forward.

Table 7. Total, Direct and Indirect Effects

\begin{tabular}{|l|c|c|}
\hline & $\begin{array}{c}\text { Environmental } \\
\text { concern }\end{array}$ & $\begin{array}{c}\text { Environmental } \\
\text { attitude }\end{array}$ \\
\hline Direct Effects & & 0,000 \\
\hline Environmental attitude & 0,365 & 0,170 \\
\hline Purchase intention & 0,148 & \\
\hline Indirect Effects & & 0,000 \\
\hline Environmental attitude & 0,000 & 0,000 \\
\hline Purchase intention & 0,062 & \\
\hline TotalEffects & & 0,000 \\
\hline Environmental attitude & 0,365 & 0,170 \\
\hline Purchase intention & 0,210 & \\
\hline
\end{tabular}

Environmental attitude has a direct impact on green product purchasing intention. Also, environmental concern has a direct impact on environmental attitude, and it has a both direct and indirect impact on green product purchasing intention. Thus, environmental attitude has a partial mediating impact on the effect of

The Mediating Role of Environmental Attitude on the Impact of Environmental Concern on Green Product 
environmental concern on green product purchasing intention.

H4: The hypothesis stating that environmental attitude has a mediating impact on the effect of environmental concern on green product purchasing intention is partially accepted.

Moreover, some specific tests are used to evaluate whether the indirect impact of independent variable on the dependent variable is meaningful (significant) or not. The mediating role of environmental attitude on the impact of environmental concern on green product purchasing intention is evaluated with the Sobel test. The mentioned test is calculated via using the moderated regression coefficients and standard deviation values of related variables. Based on the Sobel test results $(Z=2,277, p<0,05)$, the mediating role of environmental concern's impact on green product puchasing intention is meaningful (significant). Also, the partial mediaing impact is verified. Thus, research hypotheses are partially accepted.

\section{Conclusion}

This study aimed to analyze the mediating role of environmental attitude on the impact of environmental concern on green product purchasing intention. Because of this reason, the effect of environmental concern on environmental attitude and green product purchasing intention was investiaged. The effect of environmental attitude on green product purchasing intention was investigated as well. In this context, exploratory factor analysis was run to ensure the validity of measurement tool and confirmatory factor analysis was run to test the dimensions. Then, Structural Equation Modelling was used to test the hypothesis.

Based on the Strutctural Equation Modelling of research;

Environmental attitude has a direct impact on green product purchasing intention. Also, environmental concern has a direct impact on environmental attitude, and it has a both direct and indirect impact on green product purchasing intention. Thus, environmental attitude has a partial mediating impact on the effect of environmental concern on green product purchasing intention.

The research found out that, environmental concern has a meaningul (significant) impact on green product purchasing intention. This is parallel to the findings of former literature such as Kim and Choi (2005); Khaola et al. (2014); Mostafa (2009) ; Lizawati Aman, A.H. (2011); Kamonthip et al. (2017); Maichum et al. (2016); Paul et al. (2016).

Findings of the study reveal that, consumers with environmental concern have intention to purchase green products to ensure the healthy life of themselves and future generations. Thus, businesses targeting green consumers or the marketing managers should position themselves as environmental friendly in order to retain consumers whose environmental concerns and consciousness levels are incresing every day. Firms should keep a close eye on all operations starting from the design of products and ending with post-purchasing experience.

Research findings indicate that, environmental attitude has a meaningful (significant) impact on green product purchasing intention. This finding is parallel with former studies such as Kim (2011); Alwitt \& Pitts (1996); Kim and Chung (2011); Cowan and Kinley (2014); Yadav and Pathak (2016); Kamonthip et al. (2017) and Coşkun (2015).

It is observed that, environmental consciousness of consumers have increased over time and they are also demonstrating environmental sensitivity. Consumers with increased environmentl sensitivity live in harmony with the nature and they prefer environmental friendly products. Thus, firms will be able to increase the green product purchasing intention of consumers if they can manufacture products not harming the nature. That will eventually attract consumers and will lead to profit generation on the business side.

It is determined that, environmental concern has a meaningful (significant) impact on environmental attitude. This finding of the research is parallel to former literature such as Mostafa (2009) ; Kamonthip et al. (2017); Maichum et al. (2016) and Paul et al. (2016).

Businesses should have social awareness and responsibility in order to stand strong and remain competitive, and for satisfying the demands of consumers with increasing environmental concern and attitude.

Future studies can include environmental consciousness (awareness) or environmental sensitivity variables to the analysis in order to investigate the mediating role of environmental concern's impact on green product purchasing intention.

When research findings are analyzed, it is observed that environmental concern has a weak and meaningful (significant) impact on green product purchasing intention, and environmental attitude has a weak and meaningful (significant) impact on green product purchasing intention. Since the impacts of variables on green product purchasing intention are weak, it is recommended that impacts of other factors on green product purchasing intention are better included in future research.

This research contributes to the literature and guides future researchers, since the mediating role of environmental attitude on the impact of environmental concern on green product purchasing intention is not adequately studied in the Turkish literature.

Future research can work with a bigger sample size, select specific products (organic products, green toys), focus on different regions of Turkey or compare two different countries in order to have a separate viewpoint and determine the mediating role of environmental attitude on the impact of environmental concern on green product purchasing intention.

Finally, the rapid increasing consumer consciousness (awareness) as a result of environmental 
concern did lead some environmentally sensitive consumers to tend towards green products. It is estimated that, most of consumers will tend towards green products over time. Thus, it is believed that firms implementing environmental friendly strategies will stand strong under fierce competition and will attract consumers who reflect environmental concern, environmental attitude and increasing consciousness (awareness) over time. Thus, the mentioned firms will higher their profit ratios and survive in the market. Furthermore, when the firms will manufacture green products, environmental damages will decrease, consumption of natural resources will go down and a healthy life will be transferred to the next generations.

\section{References}

Aaker, D.A., Kumar,V., Day, G.S. (2007). Marketing Research. 9. Edition, John Wiley \& Sons, Danvers.

Akdemir, G. (2008). Tüketicilerin Kurumsal Sosyal Sorumluluk Uygulamalarını Yürüten İşletmelere Karşı Tutumları ve GSM Sektörü Üzerinde Bir Araştırma, Yüksek Lisans Tezi, İstanbul Üniversitesi Sosyal Bilimler Enstitüsü.

Akehurst, G., Afonso, C. ve Gonçalves, H. M. (2012). "Re-Examining Green Purchase Behaviour and The Green Consumer Profile: New Evidences" Management Decision, 50 (5): 972988.

Alnıaçık, Ü. (2009). "Tüketicilerin Çevreye Duyarlılığı ve Reklamlardaki Çevreci İddialar”, Kocaeli Üniversitesi Sosyal Bilimler Enstitüsü Dergisi, (18), 48-79.

Alwitt, L. F., \& Pitts, R. E. (1996). Predicting Purchase Intentions for an Environmentally Sensitive Product. Journal of Consumer Psychology, 5 (1), 49-64.

Arıkan, R. (2007). Araştırma Teknikleri ve Rapor Hazırlama, 6.Bask1, ISBN:9758784-35-8, Ankara.

Ay, C. ve Ecevit, Z. (2005). "Çevre Bilinçli Tüketiciler”, Akdeniz İ.İ.B.F. Dergisi, 10, 238-263.

Aydın. O. (2000). Davranış Bilimlerine Giriş. Eskişehir: Anadolu Üniversitesi Yayınları No: 1027.332.
Baron, R. M. ve Kenny, D. A. (1986). "The Moderator-Mediator Variable Distinction in Social Psychological Research: Conceptual, Strategic, and Statistical Considerations", Journal of Personality and Social Psychology, 51(6), 1173-1182.

Berens, G., Cees B.M., van Riel., Gerrit H. and van Bruggen (2005). "Corporate Associations and Consumer Product Responses: the Moderating Role of Corporate Brand Dominance," JM, 69, $35-48$.

Bergeron, J. (2004). Antecedents and Consequences of Salesperson Listening Effectiveness in Buyer-Seller Relationships. The John Molson School of Business, Canada, Doktora Tezi.

Biner, N. (2014). Tüketicilerin Yeşil Ürün Satın Alma Davranışlarının İncelenmesi, Trakya Üniversitesi Sosyal Bilimler Enstitüsü, İşletme Anabilim Dalı Yüksek Lisans Tezi.

Boztepe, A. (2012). "Green marketing and its impact on consumer buying behavior"s European Journal of Economic and Political Studies, 5 (1), 5-21.

Büyüköztürk, Ş. (2002). Sosyal bilimler için veri analizi el kitabı. 2. Baskı. Ankara: Pegem Yayıncilık.

Byrne, B. M. (2010). Structural Equation Modeling with AMOS: Basic Concepts, Applications, and Programming, 2nd ed., Taylor and Francis Group, ISBN 978-0- 80586372-7 (hardcover: alk. paper) ,ISBN 978-0-8058-6373-4.

Coşkun, A. (2015). Yeşil Satın Alma Niyetini Belirleyen Psikografik Faktörler: Düşük İlgilenimli Ürün Örneği, Selçuk Üniversitesi Sosyal Bilimler Enstitüsü İşletme Anabilim Dalı.

Cowan, K. and Kinley, T. (2014). Green spirit: consumer empathies for green apparel. International Journal of Consumer Studies, 38 (5), 493-499. 
Çabuk, S., Nakıboğlu, B. ve Keleş, C. (2008). Tüketicilerin Satın Alma Davranışlarının Sosyo-Demografik Değişkenler Açısından İncelenmesi. Ç.Ü. Sosyal Bilimler Enstitüsü Dergisi, 17(1), 85-102.

Çetin Gürkan, G. ve Demiralay, T. (2017). Bireysel Yenilikçiliğin Çalışanın Yenilikçi Davranışı Üzerindeki Etkisinde İçsel Motivasyonun Aracılık Rolü: Türkiye'de Cerrahlar Örneği, Girişimcilik ve İnovasyon Yönetimi Dergisi, 6 (1).

DiLalla, Lisabeth F. (2000) Structural equation modeling: Uses and issues. In H. E. A. Tinsley and S. D. Brown (Eds.), Handbook of Applied Multivariate Statistics and Mathematical Modeling, 439-464. San Diego: Academic Press.

Dodds, W.B., Kent B. Monroe, and Dhruv G. (1991). "The Effects of Price, Brand, and Store Information on Buyers' Product Evaluations," JMR, 28 (August), 307-319.

Elkington, J. (1994). "Toward The Sustainable Corporation:Win -Win -Win Business Strategies For Sustainable Develpoment", California Management Review, 36, 90- 100.

Engel, J. F. Blackwell, R. D., \& Miniard, P. W. (1995). Consumer behavior ( 8th ed.) New York: Dryden Press.

Erbaşlar G. (2007). "Yeşil Pazarlama". Paradoks Ekonomi, Sosyoloji ve Politika Dergisi. 3(1).

Farr, A. and Hollis, N. (1997). What do you want your brand to be when it grows up? big and strong? Journal of Advertising Research, 37(6), 23-36.

Fishbein, M. and Ajzen, I. (1975). Belief, attitude, intention, and behavior: an introduction to theory andresearch. Reading. MA: Addison-Wesley.

George, D. ve Mallery, P.(2003). SPSS for Windows step by step: A Simple guide and reference 11.0 Update. Pearson Education, Inc, United States Of America.
Grewal D., Krishnan R., Baker J., Borin N. (1998). "The Effect of Store Name, Brand Name and Price Discounts on Consumers' Evaluations and Purchase Intentions", Journal of Retailing, 74 (3), 331-352.

Guanghui Ma, Pei-Luen Patrick Rau and Zhi G. (2018). The Effects of Environmental Awareness and Consumption Value on Green Makeup Product Purchase Intentions, Psychology, 9, 1898-1916.

Hines, J. M., Hungerford, H. R., \& Tomera, A. N. (1987). Analysis and Synthesis of Research on Responsible Environmental Behavior: A MetaAnalysis. The Journal of Environmental Education, 18(2), 1-8.

Henson, R. K. ve Roberts, J. K. (2006). Exploratory factor analysis in published research: Common errors and some comment on improved practice. Educational and Psychological Measurement, 66(3), 393-416.

Hoyle, R. H. (1995). Structural Equation Modeling: Concepts, Issues and Applications. Sage Publication Inc. London.

İncelioğlu, M. (2010). Tutum Algı İletişim, Beykent Üniversitesi Yayınları, İstanbul.

Kalafatis, S. P., Pollard, M., East, R., \& Tsogas, M. H. (1999). Green Marketing and Ajzen's Theory of Planned Behaviour: a Cross-Market Examination. Journal of Consumer Marketing, 16(5), 441-460.

Kamonthip, M., Surakiat, P. Ve Ke-Chung, P. (2017). The Influence of Environmental Concern and Environmental Attitude on Purchase Intention towards Green Products: A Case Study of Young Consumers in Thailand, International Journal of Business Marketing and Management (IJBMM), 2 (3): 1-8. 
Kanchanapibul, M., Lacka, E., Wang, X. and Chan, H. K. (2014). An empirical investigation of green purchase behaviour among the young generation. Journal of Cleaner Production, 66, 528536.

Karaca, Ş. (2013). “Tüketicilerin Yeşil Ürünlere İlişkin Tutumlarının İncelenmesine Yönelik Bir Araştırma", Ege Academic Review", 13(1).

Kelly, S. (2011), "Do Homes that are More Energy Efficient Consume Less Energy? A Structural Equation Model for England's Residential Sector", Electricity Policy Research Group, University of Cambridge, EPRG Working Paper 1117, Cambridge Working Paper in Economics 1139.

Khaola, P.P., Potıane, B. and Mokheth1, M. (2014). Environmental Concern, Attitude Towards Green Products And Green Purchase Intentions Of Consumers In Lesotho, Ethiopian Journal of Environmental Studies \& Management 7(4): 361 - 370,

Kim, Y. and Han, H. (2010). Intention to pay conventional-hotel prices at a green hotel-a modification of the theory of planned behavior. Journal of Sustainable Tourism, 18 (8), 997-1014.

Kim, H. Y., \& Chung, J.-E. (2011). Consumer purchase intention for organic personal care products. Journal of Consumer Marketing, 28 (1), 40-47.

Kim, Y. (2011). Understanding Green Purchase: The Influence of Collectivism, Personal Values and Environmental Attitudes, and the Moderating Effect of Perceived Consumer Effectiveness. Seoul Journal of Business, 17 (1), 65-92.

Kim, Y. J., Njite, D. and Hancer, M. (2013). Anticipated emotion in consumers' intentions to select eco-friendly restaurants: Augmenting the theory of planned behavior. International Journal of Hospitality Management, 34, 255262.
Kline, Rex. B. (2005) Principles and Practice of Structural Equation Modeling. New York: The Guilford Press.

Laroche, M., Bergeron, J. and Barbaro-Forleo, G. (2001). Targeting Consumers Who Are Willing to Pay More for Environmentally Friendly Products. Journal of Consumer Marketing, 18( 6), 503-520.

Lizawati Aman, A.H. (2011). The influence of environmental knowledge and concern on green purchase intention. The role of attitude as mediating variable. Masters thesis, Universiti Malaysia Sabah.

Madahi, A. ve Sukati, I. (2012). The Effect of External Factors on Purchase Intention Amongst Young Generation in Malaysia, International Business Research, 5(8), 153-159.

Maichum, K., Parichatnon, S. and Peng, K.C. (2016). Application of the Extended Theory of Planned Behavior Model to Investigate Purchase Intention of Green Products among Thai Consumers. Sustainability, 8(10), 1077.

Mark, N. and Law, M. (2015). Encouraging Green Purchase Behaviours of Hong Kong Consumers. Asian Journal of Business Research ISSN, 5(2), 2015.

Meydan, C. H. ve Şeşen, H. (2011). Yapısal Eşitlik Modellemesi AMOS Uygulamaları (1 ed.). Ankara: Detay Yayınevi.

Minton, A. P. ve Rose, R. L. (1997). “The effects of environmental concern on environmentally friendly consumer behavior: An exploratory study", Journal of Business Research, 40 (1): $37-48$.

Moisander, J. (2007). Motivational Complexity of Green Consumerism, International Journal of Consumer Studies, 31:404409.

Morris, J. (1997). Green Goods? Consumers, Product Labels and the Environment. London: UK: IEA Environment Unit. 
Mostafa, M. M. (2009). Shades of green: A psychographic segmentation of the green consumer in Kuwait using selforganizing maps. Expert Systems with Applications, 36 (8), 11030-11038.

Newhouse, N. (1990). Implications of Attitude and Behavior Research for Environmental Conservation, The Journal of Environmental Education, 22 (1): 26-32.

Onurlubaş, E. ve Dinçer, D. (2016). Yeşil Pazarlama Tüketici Algısı Üzerine Bir Araştırma, İstanbul: Beta.

Oppenheim AN. (1992). Questionnaire Design, Interviewing and Attitude Measurement. New edition. New York: Printer Publishers,

Ottman, J., Stafford, E. R. ve Hartman, C. I. (2006). "Avoiding Green Marketing Myopia: Ways to Improve Consumer Appeal for Environmentally Preferable Products". Environment, 48(5).

Özdamar, K. (1999). Paket programlar ile istatistiksel veri analizi. Eskişehir: Kaan Kitabevi.

Paço, A., Alves, H., Shiel, C. ve Filho, W. L. (2013), Development of a Green Consumer Behaviour Modele $^{\text {ee }}$ International Journal of Consumer Studies, 37 (4), 414-421.

Paul, J., Modi, A., and Patel, J. (2016). Predicting green product consumption using theory of planned behavior and reasoned action. Journal of Retailing and Consumer Services, 29, 123-134.

Petroshius, S.M. and Kent B. M. (1987), "Effect of Product-Line Pricing Characteristics on Product Evaluations," JCR, 13 (March), 511519.

Sabuncu, R.G. (2017). Anadolu Üniversitesi İşletme Fakültesi Öğrencilerinin Girişimcilik Niyetleri Ve Çevresel Tutumlarını Ölçmeye Yönelik Bir Araştırma, Anadolu Üniversitesi, Sosyal Bilimler Enstitüsü, Yüksek Lisans Tezi.
Schultz, P. W., Shriver, C., Tabanico, J. J. and Khazian, A. M. (2004). Implicit connections with nature. Journal of Environmental Psychology, 24(1), 3142.

Shamdasani, P., Ong Chon-Lin, G. and Richmond, D. (1993). Exploring Green Consumers In An Oriental Culture: Role Of Personal And Marketing Mix Factors. Advances in Consumer Research (20), s. 488-493.

Shrum, L.J., John A. McCarty and Tina M. L. (1995), "Buyer Characteristics Of The Green Consumer And Their Implication For Advertising Strategy", Journal of Advertising, 24 (2), 71-81.

Sipahi B., Yurtkoru, E.S. ve Çinko M. (2008). Sosyal Bilimlerde SPSS ile Veri Analizi, İstanbul: Beta Yayınları.

Stevens, J. P. (2002). Applied multivariate statistics for the social sciences. New Jersey: Lawrance Erlbaum Association, Inc.

Straughan, R. D. ve Roberts, J. A. (1999). Environmental segmentation alternatives: a look at green consumer behavior in the new millennium. Journal of Consumer Marketing, 16 (6): 558-575.

Tabachnick, B. G. ve Fidel, L. S. (2014). Using multivariate statistics. USA: Pearson Education Limited

Timm, H. N. (2002). Applied Multivariate Analysis. Springer - Verlag New York.

Tomer, A. (2003). A Short History Of Structural Equation Models, Structural Equation Modeling: Applications In Ecological And Evolutionary Biology. B. Pugesek (Ed.), Cambridge University Press, 85-12.

Turhan, E., Gültekin, Ö.. Özdemir, Y. (2015). Yeşil ergonomiye genel bakış, Süleyman Demirel Üniversitesi Mühendislik Bilimleri ve Tasarım Dergisi, 3 (3): 559-565.

TÜíK, (2018). http://www.tuik.gov.tr 
Uysal, O.U. (2006). Yeşil Ürünlerde Konumlandırma ile İlgili Uygulama, Yüksek Lisans Tezi, Marmara Üniversitesi Sosyal Bilimler Enstitüsü, İstanbul.

Wu P.C.S, Yeh G.Y.Y. and Hsiao C.R. (2011). "The Effect of Store İmage and Service Quality on Brand İmage and Purchase Intention for Private Label Brands", Australasian Marketing Journal, 19, 3039.

Yadav, R. and Pathak, G. S. (2016). Young consumers' intention towards buying green products in a developing nation: Extending the theory of planned behavior. Journal of Cleaner Production, 135, 732-739.

Zinkhan, G.M. ve Les C. (1995), “Green Advertising and the Reluctant Consumer", Journal of Advertising, 24 (2): 1-6. 